\title{
Concept Map Technique as a New Method for Whole Text Translation
}

\author{
Tamara Mohd Altabieri Krishan ${ }^{1}$ \\ ${ }^{1}$ Department of basic science, Maan Collage, Al-Balqa Applied University, Maan, Jordan \\ Correspondence: Tamara Mohd Altabieri Krishan, Department of basic science, Maan Collage, Al-Balqa \\ Applied University, Maan, Jordan. Tel: 962-3213-2299. E-mail: tamarakrishan@yahoo.com
}

Received: January 30, 2017 Accepted: March 4, 2017 Online Published: March 6, 2017

doi: $10.5539 /$ elt.v10n4p62 URL: http://doi.org/10.5539/elt.v10n4p62

\begin{abstract}
This study discusses the use of concept map tool as a new method for teaching translation (from English language to Arabic language). This study comprised 80 students divided into two groups. The first group was taught the new vocabulary by using the concept tool method, whereas the second group was taught the new vocabulary by the traditional method. Pre-test and test of homogeneity was administered in order to ensure the equivalence of the students. During the training, the two groups were subjected to evaluation tests (first, second and final) in which the students were asked to summarize text into a paragraph by translation. The differences between the two methods were compared by using t-test. Results of pre-test indicated that the difference between the two groups was not significant and the scores were linearly distributed. Results of students' scores between the two groups for the first exam was not significant, however, the difference between the two groups for second, final and total scores was significant. It was seen that the introduced method of text translation improves the student skills compared with the traditional method.
\end{abstract}

Keywords: learning, translation, skills and concept mapping

\section{Theoretical Background}

Students who learn English as a foreign language read word by word in their attempt to understand the meaning of text without deciding which words are the most important to help in understanding the whole text (Kim and Clariana, 2015; Kathleen, 2013). In the traditional method of teaching, the teachers train students to employ whatever techniques that may help them to extract general meaning of the text (Kaplan and Norton, 1996 and Lawson et al., 1998). Foreign language teachers' methods varied and they were dependent on the way in which approach emphasized different language skills (Miller, 2007). Prevailing approaches to foreign language teaching are influenced by contemporary trend in linguistics (Langacker, 2001). Little attention was given to the techniques that could help students to develop their skills in translation of English text into another language (Meyer, 2001). Concept map tool is a web-based, online version that runs on all modern web browsers. It is designed to be utilized from a desktop or laptop and is not meant to be used by web browsers on tablets and smart phones that rely on tapping (Dagenais et al., 2012). Concept maps are graphical tools for organizing and representing knowledge. They include concepts, usually enclosed in circles or boxes of some type, and relationships between concepts indicated by a connecting line linking two concepts (Tomson, 1997). Words on the line, referred to as linking words or linking phrases, specify the relationship between the two concepts (Chang, 2011). Translation performance can be improved when the methods and strategies are specifically targeted and taught with the purpose of developing the empirical research based on translation and interpreting studies (Yingjun, 2014). The objective of this study is to investigate the effectiveness of concept map method of teaching vocabulary translation on student achievements compared with traditional method.

\section{Method}

The study sample consisted of selected 80 students and they were grouped into two. Then a pre-test and test of homogeneity was administered in order to ensure the equivalence of the students. The first group was taught the new paragraph by using the traditional method (word by word translation of English to Arabic language), whereas the second group was taught the text translation by the concept tool method for a semester. During the training, the two groups were subjected to evaluation tests (first, second and final). The differences in the students' achievements after training by the two methods were compared by using t-test. Experiment design by using concept map tools that were used in the study is shown in figure1. Students were asked to summarize the 
text into a paragraph with translation

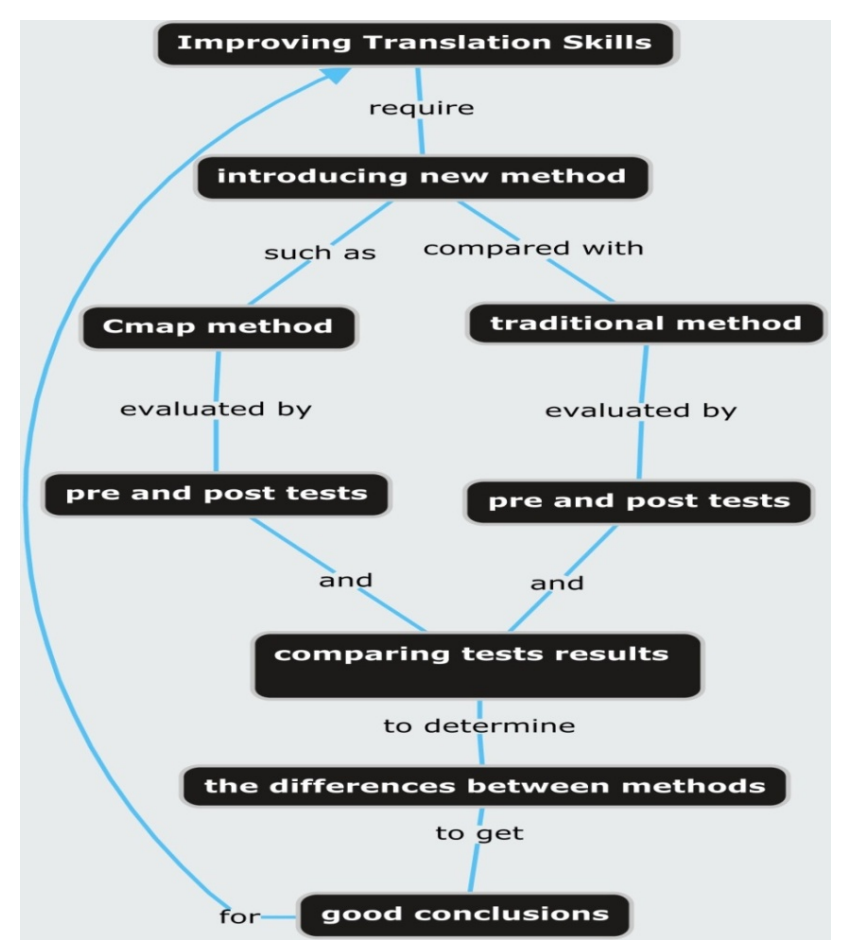

Figure1. Experiment design by using concept map tool that was used in the study

\section{Results}

The equivalence of students was determined by pre-test and test of homogeneity. Table 1 shows the mean scores of the two groups of students for the pre-test exam, the difference between the two groups was not significant and the scores were linearly distributed.

Table 1. Mean scores of the two groups of students in the pre-test exam and the test of homogeneity

\begin{tabular}{|c|c|c|c|}
\hline Group & No of students & Mean scores of Pre-test & Test of homogeneity \\
\hline Group 1 (traditional method) & 40 & 11.83 & value was $>0.05$ \\
\hline Group2 (concept map method) & 40 & 11.21 & $\begin{array}{l}\text { The difference is not } \\
\text { significant. Scores was } \\
\text { linearly distributed }\end{array}$ \\
\hline
\end{tabular}

\subsection{Student Scores of First Exam}

A one-hour post test was conducted for Group 1 (traditional method) and Group 2 (concept map method), the differences in the students' achievements of two methods were compared by using t-test (Table 2). The difference between the two groups (traditional and concept map method was not significant, and the mean scores were $13.6 \%$ and $15.2 \%$ respectively. 
Table 2. The scores of the learners in the first exam after traditional and concept map method training

\begin{tabular}{llll}
\hline Group & No of students & $\begin{array}{l}\text { Mean scores of first exam t- test } \\
(25 \%)\end{array}$ \\
\hline Group 1 (traditional method) & 40 & $\begin{array}{l}13.6 \mathrm{a}^{*} \\
15.2 \mathrm{a}\end{array}$ & $\begin{array}{l}\text { value was }>0.05 \\
\text { Group 2 (concept map method) }\end{array}$ \\
& & $\begin{array}{l}\text { The difference between } \\
\text { two groups was not } \\
\text { significant }\end{array}$ \\
\hline
\end{tabular}

*According to t-test, the difference between two groups was not significant.

\subsection{Student Scores of Second Exam}

A one-hour post test was consducted for Group 1 (traditional method) and Group 2 (concept map method), the differences of students' achievements of two methods were compared by using t-test, (Table 3 ). The mean scores of group 2 (concept map method) students $(17.7 \%)$ was significantly higher than that of group 1 (traditional method) students (11\%).

Table 3. The second exam scores of traditional and concept map method

\begin{tabular}{llll}
\hline Group & No of students & $\begin{array}{l}\text { Mean scores of second } \\
\text { exam }(25 \%)\end{array}$ & t- test \\
\hline Group 1 (traditional method) & 40 & $11.0 \mathrm{a}^{*}$ & value was $<0.05$ \\
Group2 (concept map method) & 40 & $17.7 \mathrm{~b}$ & $\begin{array}{l}\text { The difference between } \\
\text { two groups was } \\
\text { significant }\end{array}$
\end{tabular}

*According to t-test, the difference between two groups was significant.

\subsection{Student Scores of Final Exam}

A two-hour post test was conducted for Group 1 (traditional method) and Group 2 (concept map method) samples. The differences in the students' achievements after their training in the two methods respectively were compared by using t-test (Table 4). Students mean scores of concept map method (31.5\%) was significantly higher than that of traditional method (25.3\%).

Table 4. Final exam scores of the learners in the traditional and concept map method

\begin{tabular}{llll}
\hline Group & $\begin{array}{l}\text { No } \\
\text { students }\end{array}$ & $\begin{array}{l}\text { of } \\
(50 \%)\end{array}$ & $\begin{array}{l}\text { Mean scores of final exam } \\
\text { t- test }\end{array}$ \\
\hline Group 1 (traditional method) & 40 & $25.3^{*}$ & value was $<0.05$ \\
Group2 (concept map method) & 40 & $31.5 \mathrm{~b}$ & $\begin{array}{l}\text { The difference between } \\
\text { two groups was } \\
\text { significant }\end{array}$ \\
\hline
\end{tabular}

*According to t-test, the difference between two groups was significant.

Total Students' scores: The mean of total students' scores in the two methods is shown in Figure 2. It can be seen that the difference between the two groups was highly significant; and the mean value of all the students' scores for traditional and concept map methods was $49.4 \%$ and $64.4 \%$ respectively. 


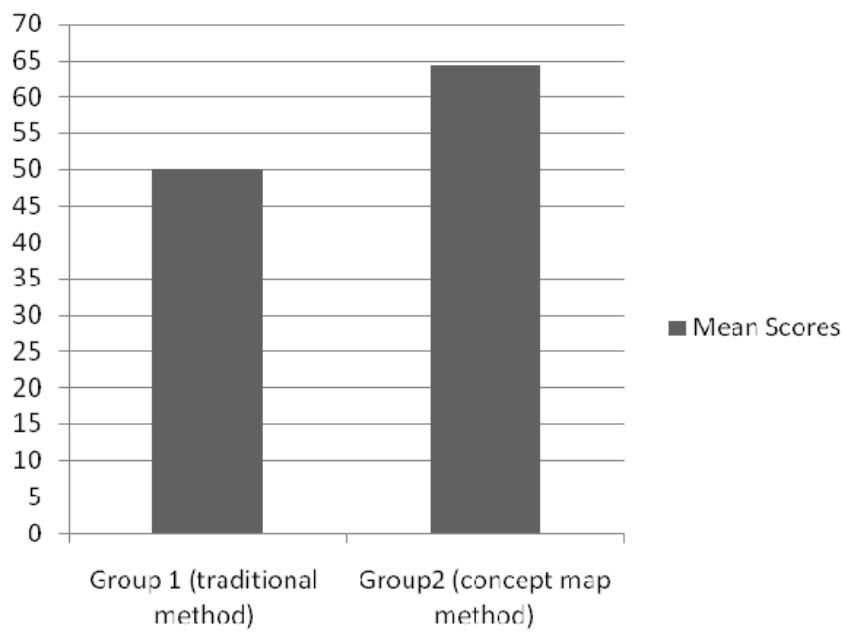

Figure 2. The mean value of total students' scores in the two methods of learning translation (traditional vs. concept map method)

\section{Discussion}

The statistical analysis of t-test, which shows the differences between the two groups, implies that the acquisition of comprehensive and translation skills of the students of group 2 who were taught by concept map method was improved when compared to the other group taking into consideration the pre-test of the two groups. This result shows that concept mapping has positive effects in text comprehension and translation skills when compared with students taught by traditional method of translation (word by word text translation). The same results were obtained by Chang et al. (2002) who demonstrated that English as a foreign language learners who use concept maps have achieved much better learning results than those who did not (Mahnamand, 2012) which means that the use of this worthwhile tool helps students to develop, one way or another, their receptive (reading \& listening) or productive (writing \& speaking) skills. The teachers play an important role in developing the skills of the students during their training using the tool. (Gruber, 1993; Service, 1993; Laviosa, 2014). Also students used concept maps to deal with information, and they understand that when concepts are placed in order, some words are more inclusive than others and concepts are connected to each other by means of linkers, which improve their teaching skills (Richardson, 2006; Kobayashi, 2001). Second language learning is facilitated when learners are engaged in interaction and meaningful communication using concept map method (Ponniah, 2010).

\section{Conclusion}

Concept mapping has positive effects in text comprehension which may help students in building translation skills and to distinguish the essential from the accessory when reading texts acquire instrumental skills for meaningful translation. The use of concept maps would be an appropriate method for improving translation skills for students. The use of concept maps in the schools will be beneficial for most of the students.

\section{References}

Chang, S. C. (2011). A Contrastive Study of Grammar Translation Method and Communicative Approach in Teaching English Grammar. English Language Teaching, 4(2). https://doi.org/10.5539/elt.v4n2p13

Chang, K., Chen, I., \& Sung, Y. (2002). The effect of concept mapping to enhance text comprehension and summarization. The Journal of Experimental Education, 71(1), 5-23. https://doi.org/10.1080/00220970209602054

Dagenais, C., Ridde, V., \& Pe'ladeau, N. (2012). The Concept mapping Methodology: A Review of Users' Evaluative Comments in 26th Annual Conference of the American Evaluation Association, Minneapolis, Minnesota, 24-27 October 2012.

Gruber, T. R. (1993). A Translation Approach to Portable Ontology. Knowledge Acquisition, 5(2), 199-220. https://doi.org/10.1006/knac.1993.1008

Kaplan, R. S., \& David, N. (1996). The Balanced Scorecard: Translating Strategy into Action. Harvard Business School Press.

Kathleen, S. (2013). Challenges and Possibilities for World Literature, Global Literature, and Translation. 
Comparative Literature and Culture, 15(7).

Kim, K., \& Clariana, R. B. (2015). Knowledge Structure Measures of Reader's Situation Models across Languages: Translation engenders Richer Structure. Technology, Knowledge and Learning, 20, 249-268. https://doi.org/10.1007/s10758-015-9246-8

Kobayashi, Y. (2011). Applied Linguistics Research on Asianness. Applied Linguistics, 32(5), 566-571. https://doi.org/10.1093/applin/amr032

Langacker, R. W. (2001). Discourse in Cognitive Grammar. Cognitive Linguistics, 12(2), 143-188. https://doi.org/10.1515/cogl.12.2.143

Laviosa, S. (2014). Special Issue on Translation in the Language Classroom: Theory, Research and Practice. The Interpreter and Translator Trainer, 8(1).

Lawson, M., \& Hogben, D. (1998). Learning and recall of foreign language vocabulary: effect of keyword strategy for immediate and delay recall. Learning and instruction, 8, 179-194. https://doi.org/10.1016/S0959-4752(97)00016-9

Mahnam, L., \& Nejadansari, D. (2012). The Effects of Different Pre-Writing Strategies on Iranian EFL Writing Achievement.International Education Studies, 5(1), 154-160. https://doi.org/10.5539/ies.v5n1p154

Meyer, B. J. F., \& Poon, L. W. (2001). Effects of Structure Strategy Training and Signaling on Recall of Text. Journal of Educational Psychology, 93(1), 141-159. https://doi.org/10.1037/0022-0663.93.1.141

Miller, L. (2007). Issues in Lecturing in a Second Language: Lecturer's Behaviour and Students' Perceptions. Studies in Higher Education, 32(6), 747-760. https://doi.org/10.1080/03075070701685163

Ponniah, R. J. (2010). Insights into Second Language Acquisition Theory and Different Approaches to Language Teaching. i-manager's Journal on Educational Psychology, 3(4), 14-17.

Richardson, R., Goertzel, B., \& Fox, E. (2006). Automatic Creation and Translation of Concept Maps for Computer Science-related Theses and Dissertations.Proceedings of the Second International Conference on ConceptMapping. San José, Costa Rica: Universidad de Costa Rica, pp. 32-35.

Service, E., \& Craik, M. (1993). Defferences between young and older adults in learning a foreign vocabulary. Journal of memory and language, 32, 608-623. https://doi.org/10.1006/jmla.1993.1031

Thomson, C. (1997). Concept Mapping as a Means of Evaluating Primary School Technology Programs. International Journal of Technology and Design Education, 7, 97-110. https://doi.org/10.1023/A:1008817221300

Yingjun, L. (2014). Status and Prospect of Machine Translation and Translation Technology Research — Mark Shuttleworth Bernard. J. Chinese Science \& Technology Translators Journal, 01, 24-27.

\section{Copyrights}

Copyright for this article is retained by the author(s), with first publication rights granted to the journal.

This is an open-access article distributed under the terms and conditions of the Creative Commons Attribution license (http://creativecommons.org/licenses/by/4.0/). 